\title{
METHODOLOGY OF DESIGNING OF HYPERMEDIA DIDACTIC PROGRAM
}

\section{Wojciech WALAT}

Resume: In this paper wrote over the component components of procedure of designing of study the hypermedia of didactic program (HDP). Work over this runs the type the program from qualification of general didactic aims, with what there is to serve the working out, across the study of tools of preliminary control, the study of strategy of teaching and at last proper projection and realization of didactic study (in our the case the HPD).

Key words: information education, media education, hypermedia didactic program

\section{METODOLOGIA PROJEKTOWANIE HIPERMEDIALNYCH PROGRAMÓW DYDAKTYCZNYCH}

Streszczenie: Jedna z kluczowych kompetencji nauczyciela jest projektowanie hipermedialnych opracowań dydaktycznych (HPD). Praca nad tego typu programem przebiega od określenia ogólnych celów dydaktycznych, jakim ma stużyć opracowywanie, a kończy przygotowanie narzędzi pomiaru kontroli bieżacej (ksztattujacej) oraz kontroli zbierającej (podsumowującej).

Stowa kluczowe: edukacja informacyjna, edukacja medialna, hipermedialne programy dydaktyczne

1. Założenia do projektowania hipermedialnych programów dydaktycznych (HPD)

Projektowanie HPD jest procesem fazowym (rys. 1). Rozpoczyna go zespół działań, które zmierzają do określenia celów dydaktycznych. Wyprowadza się je na podstawie określenia potrzeb edukacyjnych będących stwierdzoną rozbieżnością pomiędzy oczekiwaniami a stanem obecnym rozwoju uczniów.

Projektowanie HPD opiera się na konieczności uwzględnienia $w$ tworzonych rozwiązaniach trzech grup czynników:

- określeniu „punktu wyjścia” rozeznaniu z czym, w jakich warunkach rozpoczyna się lekcję;

- określeniu „punku dojścia”, tj. celu do jakiego lekcja ma doprowadzić;

- przewidywaniu działań nauczyciela i uczniów, metod nauczania i uczenia się, środków dydaktycznych, form organizacyjnych pracy uczniów zespolonych wspólna ideą jak najbardziej skutecznych, ekonomicznych od ,punktu wyjścia” do „punktu dojścia”.

Podobną strukturę postępowania w zakresie przygotowywania procesu nauczania-uczenia się multimedialnego podaje [Strykowski W., Strykowska J., Pielachowski J.: 2003]:
1) określenie celów i zadań kształcenia,

2) dobór i układ treści kształcenia,

3) wybór toku i metod prowadzenia zajęć (realizacji procesu dydaktycznego),

4) ustalenie zadań realizacyjnych dla środków dydaktycznych,

5) dobór spośród istniejących oraz zaprojektowanie i wykonanie brakujących materiałów dydaktycznych,

6) sporządzenie konspektu-scenariusza zajęć.

Obie procedury są ze sobą zgodne, z tym, że przyjęty w tym opracowaniu tok postępowania obejmuje również weryfikację multimedialnego programu dydaktycznego oraz uwzględnia psychofizyczne właściwości uczniów w momencie uczenia się z tego programu.

Bardziej ogólna nie tyle procedura, co lista kryteriów (czy też czynników), które należy brać pod uwagę przy ustalaniu zadań możliwych do zastosowania dla projektowanych programów dydaktycznych zawiera:

1) kryterium celów - środki dydaktyczne należy dobierać z punktu widzenia celów zajęć, czyli zakładanych efektów w zakresie wiedzy, umiejętności i postaw uczniów;

2) kryterium treści - decydującym czynnikiem determinującym dobór środków dydaktycznych są treści zajęć, a zwłaszcza ich właściwości fizykalne: statyczność lub 
dynamiczność, realność lub abstrakcyjność, jednobarwność lub wielobarwność;

3) kryterium właściwości uczniów program należy dostosować do poziomu wiedzy, doświadczenia, inteligencji, typu osobowości i zdolności poznawczych;

4) kryterium właściwości nauczyciela jak pisze [Kuligowska K.: 1984: 189-194]: Sadzę, że nie ma $w$ Polsce nauczyciela, który świadomie prowadzi złe, nieefektywne lekcje. Nie ma nauczyciela, który doktada starań, aby jego uczniowie niewiele z lekcji korzystali, który celowo tak organizuje prace, by lekcja byta „czasem straconym” dla uczniów, udręka dla wszystkich $w$ niej uczestniczacych; jednak nie wszyscy nauczyciele w zadowalającym stopniu opanowali biegłość pracy $\mathrm{z}$ programem i potrafią go zastosować w każdej, wymagającej tego, sytuacji dydaktycznej; często preferują bezpośredni kontakt $\mathrm{z}$ uczniem, podczas, gdy w ich opinii tego typu opracowania dydaktyczne kontakt ten ograniczają, czy wręcz eliminują, piszą o tym również inni autorzy [Szotkowski R. 2007, Lib 2006, Chráska M., Chrásková M. 2007; Dostál J. 2007; Kropáč J., Kropáčová J. 2007; Pavelka 2006];

5) kryteria ekonomiczne - często nakład pracy i poniesionych kosztów na przygotowanie HPD jest niewspółmierny do uzyskanych efektów dydaktycznych;

6) kryteria organizacyjno-techniczne należy wziąć pod uwagę czasochłonność wykorzystania HPD w czasie zajęć; gwałtowne zmiany dominujących rodzajów aktywności uczniów w czasie zajęć, np. z recepcyjnej i intelektualnej (słuchanie wykładu, pogadanki) na sensoryczną, emocjonalną i intelektualną (oglądanie filmu $\mathrm{z}$ jednoczesnym sporządzaniem jego streszczenia) prowadzi do szybkiego zmęczenia i dekoncentracji.

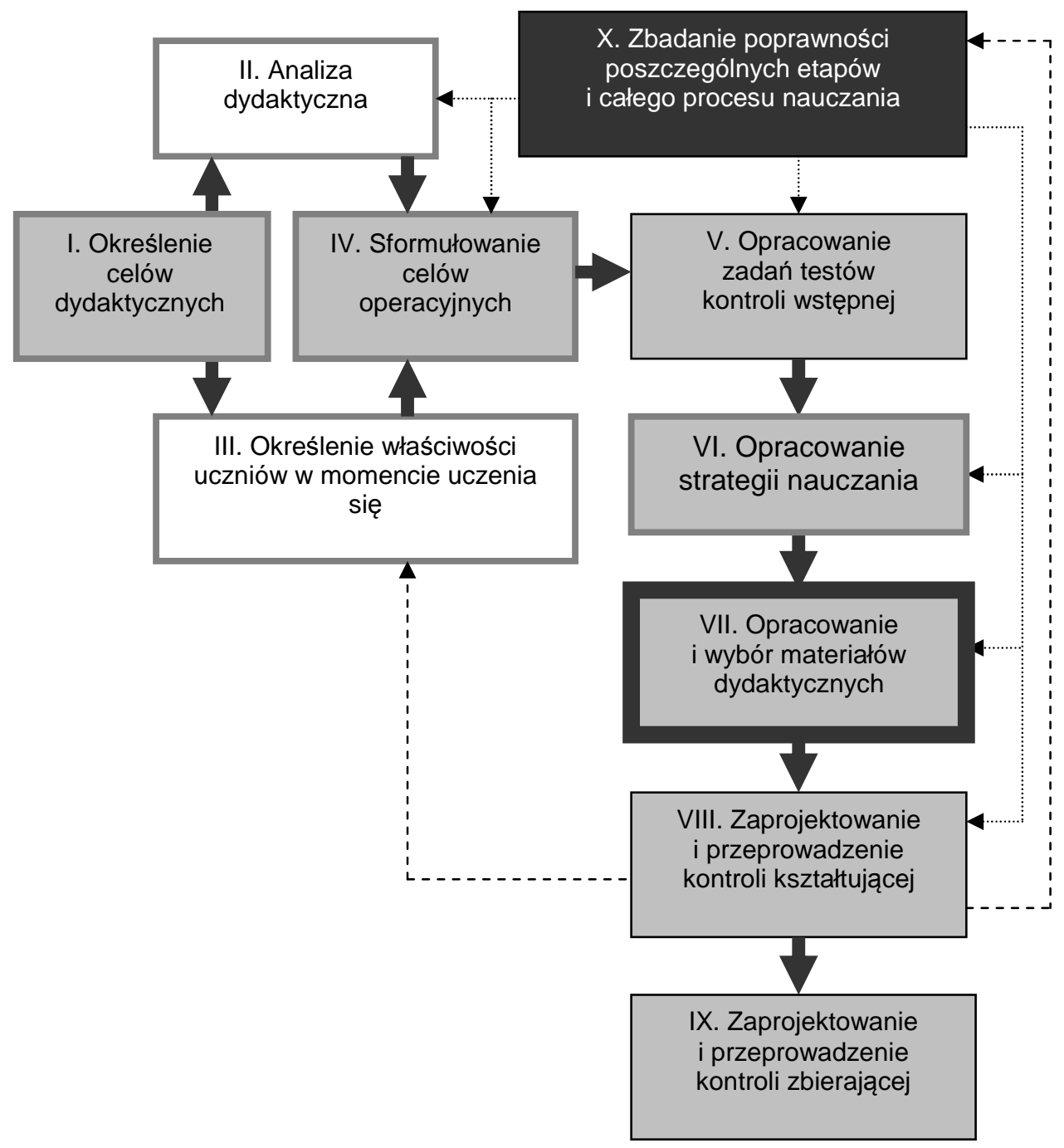

Rys. 1: Model podejścia systemowego do projektowania hipermedialnych programów dydaktycznych. 
2. Główne komponenty procedury projektowania hipermedialnych opracowań dydaktycznych

\section{Określenie celu projektowanego programu}

Procedura projektowania jakiegokolwiek działania dydaktycznego rozpoczyna się od ustalenia jego celu (rys. 1). Celem tym jest zawsze ustalenie tego, jakie zdatności ma przyswoić sobie uczeń w wyniku nauczania. $S a$ formułowane wcześniej niż treść nauczania, sa pierwotne wobec tej treści. Ich określenie jako wymiaru treści nauczania pozwoli na kontrole tej treści ze względu na cele, to znaczy takie sformułowanie treści, by cele mogty być osiagnięte [Niemierko 1991]. W formułowaniu celów nauczania należy po pierwsze odpowiedzieć sobie na pytanie czy dotyczą one bezpośrednio zmian, jakie mają zajść w zachowaniu (postępowaniu ucznia), np. uczeń opanuje klasyfikację czworokątów, czy dotyczą pracy nauczyciela, np. uczeń zainteresuje się historią misji kosmicznych. Ta pierwsza grupa celów dotyczy rzeczywistego zamiaru doprowadzenia uczniów do odpowiednich umiejętności (w określonym czasie). Drugą grupę stanowią cele dotyczące pożądanych kierunków zmian w podejmowanych działaniach przez uczniów.

\section{Analiza dydaktyczna}

Istotą analizy dydaktycznej jest określenie, jakie umiejętności uczeń musi posiadać przed podjęciem uczenia się, a jakie w trakcie, aby osiągnąć założony cel (rys. 1). Jeżeli będzie to umiejętność posługiwania się edytorem tekstu, to należy poprzez analizę dydaktyczną rozpoznać, jakie umiejętności składowe należy opanować. Taką analizę nazwać można proceduralną polegającą na określeniu listy kolejnych czynności składających się na daną procedurę. Efektem tej analizy może być opracowanie algorytmu dla danej umiejętności.

\section{Określenie właściwości uczniów w momencie uczenia się}

Uczenie się nie jest nigdy budowaniem „na pustym polu". Uczniowie przychodzą do szkoły $\mathrm{Z}$ całym bagażem swoich doświadczeń środowiskowych (rys. 1). Wiedzą, umiejętnościami i wartościami przyswojonymi i utrwalonymi poza szkołą. Oczywiście ten stan będzie bardzo różny dla poszczególnych uczniów. Od nauczyciela-projektanta HPD wymaga się określenia tego stanu początkowego, nazwijmy to „na wejściu” procesu uczenia się. Musi on zdecydować od czego zacząć nauczanie, co dla jednych uczniów będzie niezbędne, a dla innych zbyteczne. A może ze względu na duże różnice indywidualne należ wprowadzić nauczanie wyrównujące (np. w przypadku posługiwania się edytorem teksu należy określić to, czy wszyscy uczniowie pracowali już $\mathrm{z}$ tym rodzajem programów komputerowych).

\section{Sformułowanie celów operacyjnych i kontrola wstępna}

W analizie dydaktycznej chodzi nie tyle o zastanowienie się, np. jak zaznajomić uczniów z prawem Ohma (jak sformatować $w$ edytorze teksu fragment ksiażki?), ale przede wszystkim poszukiwanie odpowiedzi na pytanie: jakie zmiany moga nastapić w psychice ucznia po takim (a jakie po innym) zaznajamianiu go $z$ prawem Ohma (formatowaniu tekstu)? Rzecz idzie zatem o wyniki - i wyniki te były zawsze przedmiotem sporów $\mathrm{w}$ z punku widzenia ich klasyfikowania i hierarchizowania, czyli budowania taksonomii. Przyjęta taksonomia jest swoistym szkieletem tworzącym program dydaktyczny (rys. 1).

\section{Wybór strategii nauczania (strategii dydaktycznej)}

Określa ona plan wspomagania uczniów w osiąganiu przez nich wyznaczonych celów. Dlatego występuję tu dalszy ciąg konsekwencji w projektowaniu dydaktycznym. Charakter wskazanych do osiągnięcia przez uczniów zdatności wyznaczy sposób ich ucznia się (rys. 1). W dydaktyce ogólnej utrwalił się podział wyróżniający cztery zasadnicze drogi (toki, strategie) uczenia się: przez przyswajanie, odkrywanie, działanie i przeżywanie.

\section{Opracowanie materiałów dydaktycznych}

Pojęcie materiałów dydaktycznych odnoszę do tych wszystkich pomocy wykorzystywanych przez nauczyciela i uczniów $\mathrm{w}$ procesie dydaktycznym. Odróżniam je od urządzeń, które służą np. do ich prezentacji. Foliogram, mapa, ilustracja, książka do wypełniania, program komputerowy będzie materiałem dydaktycznym, natomiast projektoskop, aparat fotograficzny, komputer będą w tym wypadku środkami dydaktycznymi. W tym znaczeniu 
HPD jest swoistym materiałem dydaktycznym, którego miejsce $\mathrm{w}$ procesie dydaktycznym wyznaczają cele operacyjne i strategia dydaktyczna. Programy te wychodzą już dużo dalej niż przypisywana im wcześniej rola upoglądowienia procesu dydaktycznego.

\section{Kontrola bieżąca (korektywna, kształtująca) i sumująca}

Nawet najlepiej przygotowany HPD może zostać poprawiony, zmieniony $\mathrm{w}$ znacznym zakresie. Zmiany te wynikać będa z $\mathrm{z}$ wniosków wyprowadzonych na podstawie obserwacji pracy uczniów z tym programem, opinii różnych nauczycieli go wykorzystujących, a przede wszystkim efektów - osiągnięć uczniów. I nie chodzi tu o tradycyjne pojmowanie skuteczności uczenia się, gdzie przyjmuje się, że nowy materiał na ocenę bardzo dobrą opanuje zaledwie kilku uczniów w klasie, a większość będą to uczniowie czwórkowi i trójkowi, a tylko kilku będzie dwójkowych - czyli rozkład wyników będzie zgodny z krzywą rozkładu normalnego. $\mathrm{W}$ procesach dydaktycznych chodzi o opanowanie założonych zdatności na poziomie co najmniej podstawowym, a najlepiej dla wszystkich uczniów pełnym. Z oczywistych względów - chociażby różnic indywidualnych pomiędzy uczniami - jest to niemożliwe (rys. 1).

\section{Podsumowanie}

Współcześnie wśród środków dydaktycznych znajdują się ciągle te klasyczne, przez wieki doskonale wzmacniające rozwój człowieka, ale pojawiają się nowe oparte na nieznanych dotad formach przekazywania informacji. Tylko rozsądne i uzasadnione ich stosowanie jest gwarancją sukcesów dydaktycznych uczniów i ich nauczycieli.

\section{Literatura}

CHRÁSKA M., CHRÁSKOVÁ M., Postoje žáků různých typů středních škol k osobnímu počítači [w:] Technika - Informatyka Edukacja. Teoretyczne i praktyczne problemy edukacji informatycznej. Suplement. Rzeszow 2007, s. 17 - 27, ISBN 978-83-88845-94-9.

DOSTÁL J., Rozvoj Celoživotního vzdělávání učitelů v oblasti využívání počítače ve vzdělávání [w:] Technika - Informatyka Edukacja. Teoretyczne i praktyczne problemy edukacji informatycznej. Tom VIII. Rzeszow 2007, s. 208 - 212, ISBN 978-83-88845-91-8. KULIGOWSKA K., Doskonalenie lekcji. WSiP, Warszawa 1984, s. 189-194, cyt. za WĘGLIŃSKA M.: Jak przygotować się do lekcji? Wybór materiałów dydaktycznych. Impuls, Kraków 1998.

LIB W., Methodology of the elaboration multimedia didactic programmes, ,Technologu and Society 2006", Zadar 2006.

NIEMIERKO B., Między oceną szkolną a dydaktyką. WSiP, Warszawa 1991.

PAVELKA J., Kl'účové zručnosti a technická výchova [w:] Technika - Informatyka Edukacja. Red. W. Walat, Rzeszów 2006. ISBN STRYKOWSKI W., STRYKOWSKA J., PIELACHOWSKI J., Kompetencje nauczyciela szkoły współczesnej. Wyd. eMPi ${ }^{2}$, Poznań 2003, s. 22-23.

SZOTKOWSKI R., Typy učitel dle využití počítače a dataprojektopru při výuce na základní škole. Infotech 2007. Olomouc 2007, s: 47 - 51. ISBN 978-80-7220-301-7.

WALAT W., Edukacyjne zastosowania hipermediów. Wyd. UR. Rzeszów 2004. ISBN 978-83-7338-329-6.

\section{Dr Wojciech WALAT \\ Uniwersytet Rzeszowski, Instytut Techniki, ul. Rejtana 16A, \\ 35-310 Rzeszów, tel. (017) 872-11-90, e-mail: walat@univ.rzeszow.pl}

